\title{
Analysis of Intergranular Precipitation in Isothermally Aged Nitrogen-Containing Austenitic Stainless Steels by an Electrochemical Method and Its Relation to Cryogenic Toughness
}

\author{
Maribel L. Saucedo-Muñoz, ${ }^{1}$ Victor M. Lopez-Hirata, ${ }^{1}$ Hector J. Dorantes-Rosales, ${ }^{1}$ \\ and Erika O. Avila-Davila ${ }^{2}$
}

${ }^{1}$ Metallurgy Department, Instituto Politecnico Nacional, Apartado Postal 75-556, 07300 Mexico, DF, Mexico

${ }^{2}$ Metal-Mechanics Department, Instituto Tecnologico de Pachuca, 42080 Pachuca de Soto, HGO, Mexico

Correspondence should be addressed to Victor M. Lopez-Hirata, vlopezhi@prodigy.net.mx

Received 14 May 2011; Revised 9 September 2011; Accepted 12 September 2011

Academic Editor: Daolun Chen

Copyright (C) 2011 Maribel L. Saucedo-Muñoz et al. This is an open access article distributed under the Creative Commons Attribution License, which permits unrestricted use, distribution, and reproduction in any medium, provided the original work is properly cited.

\begin{abstract}
The precipitation process in two $\mathrm{N}$-containing austenitic stainless steels, aged at temperatures between 873 and $1173 \mathrm{~K}$ for times from 10 to $1000 \mathrm{~min}$, was analyzed by an electrochemical method based on the anodic polarization test with an electrolyte of $1 \mathrm{~N} \mathrm{KOH}$ solution. The anodic polarization curves showed the following intergranular precipitation sequence: austenite $\rightarrow$ austenite $+\mathrm{Cr}_{23} \mathrm{C}_{6} \rightarrow$ austenite $+\mathrm{Cr}_{23} \mathrm{C}_{6}+\mathrm{Cr}_{2} \mathrm{~N}$. Besides, the fastest precipitation kinetics was detected in the aged steel with the highest content of nitrogen and carbon due to its higher driving force for precipitation. The higher the aging temperature, the higher volume fraction of precipitates. The precipitation fraction can be associated with the current density of the dissolution peaks of each phase. The Charpy-V-Notch impact energy of the aged specimens decreased with the increase in the volume fraction of precipitates.
\end{abstract}

\section{Introduction}

The austenitic stainless steels are construction materials for key corrosion-resistant equipment in most of the major industries, particularly in the chemical, petroleum, and nuclear power industries [1]. These steels are iron alloys containing a minimum of approximately $12 \%$ chromium. This content of chromium allows the formation of the passive film, which is self-healing in a wide variety of environments.

In the case of austenitic stainless steels, the main reason for the development of nitrogen-containing steels is due to the higher yield and tensile strengths achieved, compared with conventionally processed austenitic stainless steels without scarifying toughness [2]. High-nitrogen stainless steels have yield and tensile strengths as much as 200-350\% of the AISI 300 series steels [3]. It is also important to notice that, in contrast to carbon, nitrogen-containing austenitic stainless steels retain high-fracture toughness at low temperatures. Therefore, the higher-mechanical properties of nitrogen-containing austenitic stainless steels have made very attractive its application in the power-generation industry, shipbuilding, railways, cryogenic process, chemical equipment, pressure vessels, and nuclear industries [3-5].

These stainless steels are also susceptible to the precipitation of different phases because of the aging for long exposition at high temperatures or during continuous cooling after welding process. Therefore, it is important to evaluate the degree of aging-induced embrittlement due to the precipitation phenomenon which may affect the cryogenic toughness in this type of steels $[6,7]$.

The electrochemical methods have proved to be a powerful tool for the evaluation of microstructural changes and sensitization in different steels [8-10]. In addition, these methods can also be applied nondestructively to evaluate the microstructural degradation of in-service equipments.

Thus, the purpose of this work is to carry out the precipitation analysis of two isothermally aged nitrogencontaining austenitic stainless steels using an electrochemical 
TABLE 1: Chemical composition of JJ and JN steels.

\begin{tabular}{lcccccccrrr}
\hline Steel & $\% \mathrm{C}$ & $\% \mathrm{~N}$ & $\% \mathrm{Si}$ & $\% \mathrm{Mn}$ & $\% \mathrm{Ni}$ & $\% \mathrm{Cr}$ & $\% \mathrm{Mo}$ & $\% \mathrm{Al}$ & $\% \mathrm{P}$ & $\% \mathrm{~S}$ \\
\hline $\mathrm{JJ1}$ & 0.025 & 0.236 & 0.48 & 10.13 & 11.79 & 12.01 & 4.94 & - & 0.021 & 0.0017 \\
$\mathrm{JN} 1$ & 0.040 & 0.32 & 0.97 & 3.88 & 15.07 & 24.32 & - & 0.023 & 0.022 & 0.001 \\
\hline
\end{tabular}

method as well as its relation to the decrease in cryogenic toughness due to the aging-induced embrittlement.

\section{Experimental Procedure}

2.1. Mechanical and Microstructural Characterization. The materials used in this work were forged plates of $200 \mathrm{~mm}$ thick of the JN1 and JJ1 austenitic stainless steels, and their composition, in weight \%, is shown in Table 1 . The solution treatment of JN1 and JJ1 steels was carried out at $1348 \mathrm{~K}$ for $30 \mathrm{~min}$ and then water-quenched. The aging treatments were conducted at temperatures from 873 to $1173 \mathrm{~K}$ for times from 10 to $1000 \mathrm{~min}$. The Charpy V-Notch (CVN) test was conducted at $77 \mathrm{~K}$, liquid nitrogen temperature, following the standard procedure. Specimens of about $10 \mathrm{~mm} \times$ $10 \mathrm{~mm} \times 10 \mathrm{~mm}$ were cut from the tested CVN impact test specimens in a spark-erosion cutting machine to conduct metallographical and electrochemical analyses. The solution was treated and the aged specimens were metallographically prepared using emery-paper up to 1500 grit number, and were polished with alumina $0.05 \mu \mathrm{m}$. After that, polished specimens were chemically etched in a solution of Villela's reagent $(1 \mathrm{~g}$ of picric acid and $5 \mathrm{~mL}$ of hydrochloric acid in $100 \mathrm{~mL}$ of ethylic alcohol) for about $2 \mathrm{~min}$. Finally, the etched samples were characterized with PME3 Olympus optical microscope (OM) and scanning electron microscope (SEM) equipped with an EDX microanalysis system. The precipitates were extracted by electrochemical dissolution of the austenitic matrix. The chemical solution used was an electrolyte of $5 \mathrm{vol}$. \% hydrochloric acid in methylic alcohol at room temperature and $6 \mathrm{~V}$ (D.C.). The extracted precipitates were analyzed in an X-ray diffractometer with monochromatic $\mathrm{K} \alpha$ copper radiation. The precipitates were also extracted from the etched samples by using the replica method to carry out a chemical microanalysis in the EDXSEM.

2.2. Electrochemical Characterization. In order to carry out the electrochemical analysis, the aged specimens were mounted in epoxy resin. A nickel wire was welded to these specimens to have electrical contact. The mounted specimens were metallographically prepared, using emery paper, up to 1500 grit number and then diamond paste, 15 , 6 , and $3 \mu \mathrm{m}$ and finally rinsed in water and then isopropyl alcohol. During the electrochemical tests, a pyrex glass cell of a capacity of 1 liter with a graphite counter electrode and a reference electrode of saturated calomel, SCE, was used. The testing electrolyte was a $1 \mathrm{~N} \mathrm{KOH}$ solution prepared with pure $\mathrm{KOH}$ and water. The temperature of electrolyte was kept constant at $298 \mathrm{~K}$. The polarization curves were determined in a potentiostat/galvanostat PAR 273-A controlled by a commercial software installed in a personal computer. The anodic curves were obtained using a swept rate of $0.2 \mathrm{mVs}^{-1}$ in the range of -450 to $450 \mathrm{mV}$. The electrochemically tested specimens were observed with optical and scanning electron microscopes to analyze the degree of etching and dissolved phases, respectively.

\section{Results}

3.1. Microstructural Characterization of Precipitation. Figures 1(a) and 1(b) show the SEM micrographs of the JJ1 and JN1 steels, respectively, aged at $1073 \mathrm{~K}$ for $300 \mathrm{~min}$. Precipitation is indicated by arrows. The highest-volume fraction of intergranular precipitates corresponded to the aged JN1 steel. Some intergranular precipitates can be observed in the JN1 aged at $1073 \mathrm{~K}$ for $300 \mathrm{~min}$, Figure 1(a). Some small transgranular precipitates in addition to the intergranular ones were also observed in the JJ1 steel aged at $1073 \mathrm{~K}$ for $300 \mathrm{~min}$, Figure 1(b). The intergranular precipitation was slightly more uniform and abundant in the aged JN1 steel, Figure 1(a), than that corresponding to the aged JJ1 steel. The precipitation of particles was also observed to occur on twin boundaries in the aged JN1 steel. The aging at $873 \mathrm{~K}$ for 60 and $500 \mathrm{~min}$ was observed to cause a poor intergranular precipitation in JN1 and JJ1 steels, respectively.

The X-ray diffraction patterns of precipitates, extracted from the JN1 and JJ1 steels, aged at 973 and $1073 \mathrm{~K}$ for $300 \mathrm{~min}$, are shown in Figure 2. The extracted precipitates of the JN1 steel were identified as $\mathrm{Cr}_{23} \mathrm{C}_{6}$ and $\mathrm{Cr}_{2} \mathrm{~N}$. In addition to these two phases, the presence of the $\left(\mathrm{Fe}_{2} \mathrm{Mo}\right) \eta$ phase was also detected in the residues of the JJ1 steel aged at 1073 and $1173 \mathrm{~K}$. The SEM microanalyses of the different precipitates showed that the intergranular $\mathrm{Cr}_{23} \mathrm{C}_{6}$ precipitates are not only composed of $\mathrm{Cr}$, but also of Fe in the JN1 steel, and of $\mathrm{Fe}$ and Mo in the JJ1 steel. The intergranular and transgranular $\mathrm{Cr}_{2} \mathrm{~N}$ precipitates are formed by $\mathrm{Cr}$ and $\mathrm{Fe}$, while the $\eta$ phase was composed of $\mathrm{Fe}$ and Mo and only precipitated in an intergranular mode.

In summary, the above results showed that the intergranular precipitation of $\mathrm{Cr}_{23} \mathrm{C}_{6}$ and $\mathrm{Cr}_{2} \mathrm{~N}$ preceded the transgranular precipitation of $\mathrm{Cr}_{2} \mathrm{~N}$ in the JN1 steel and the transgranular precipitation of $\mathrm{Cr}_{2} \mathrm{~N}$ and the $\eta$ phase in the JJ1 steel. Besides, the kinetics of intergranular precipitation for JN1 steel was faster than that of JJ1 steel, because of its higher interstitial solute content and thus higher driving force for precipitation [11]. It was also observed that the higher the aging temperature, the higher volume fraction of precipitates.

3.2. Electrochemical Characterization. The anodic polarization curves of JJ1 and JN1 steels, after solution treatment are 


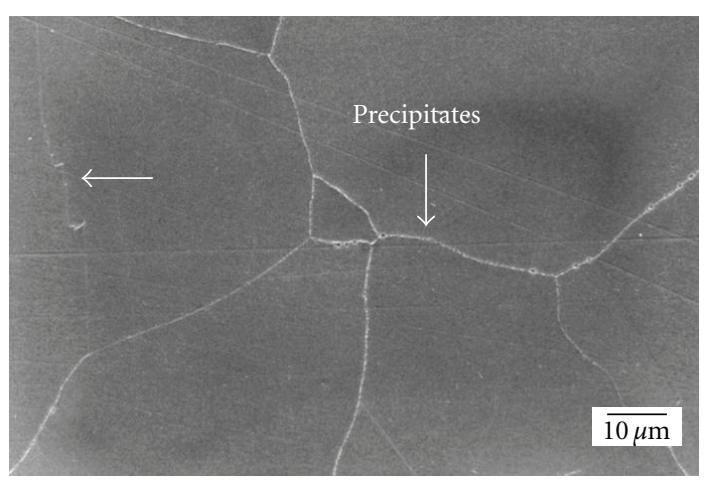

(a)

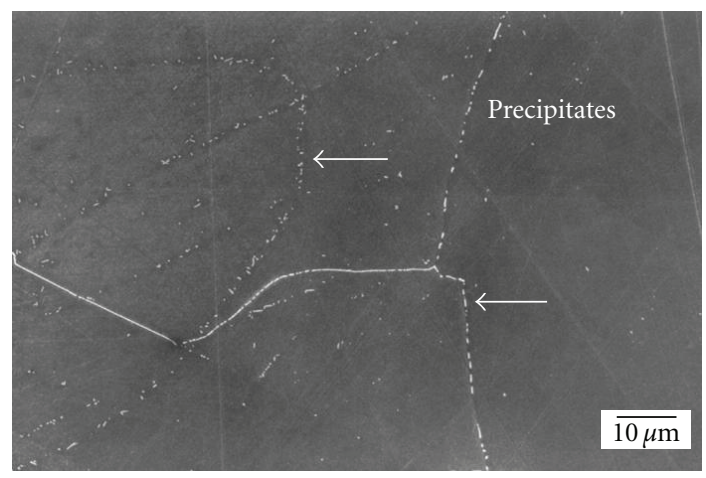

(b)

FIGURE 1: SEM micrographs the (a) JN1 and (b) JJ1 steels aged at $1073 \mathrm{~K}$ for $500 \mathrm{~min}$.

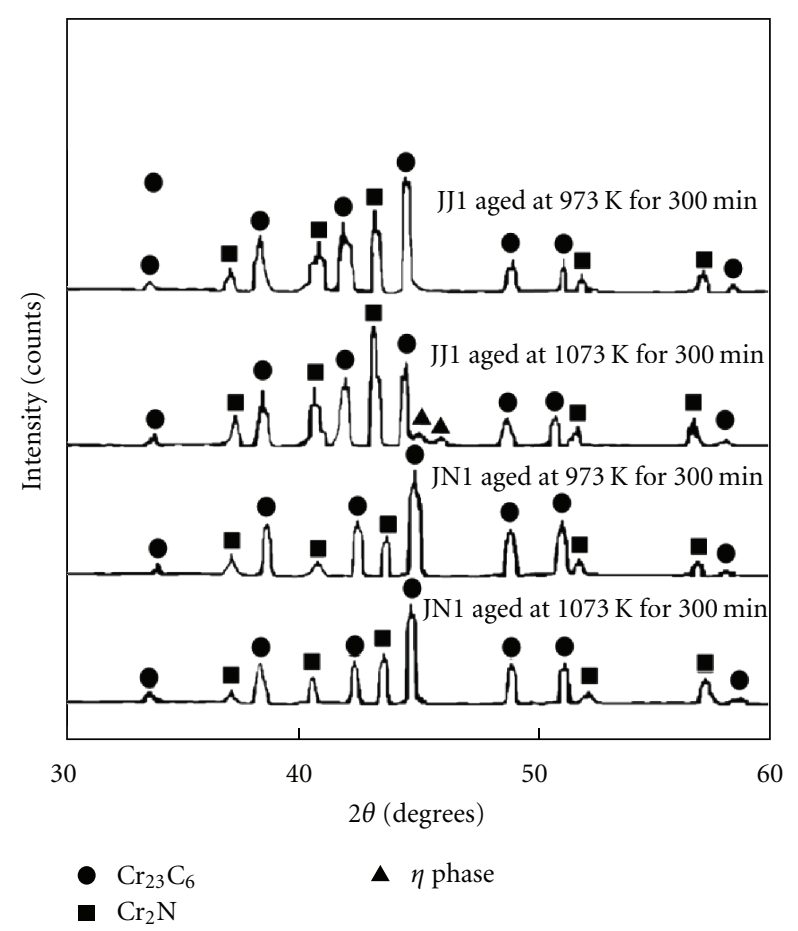

FIGURE 2: XRD patterns of the JJ1 and JN1 steels aged at 973 and $1073 \mathrm{~K}$ for $500 \mathrm{~min}$.

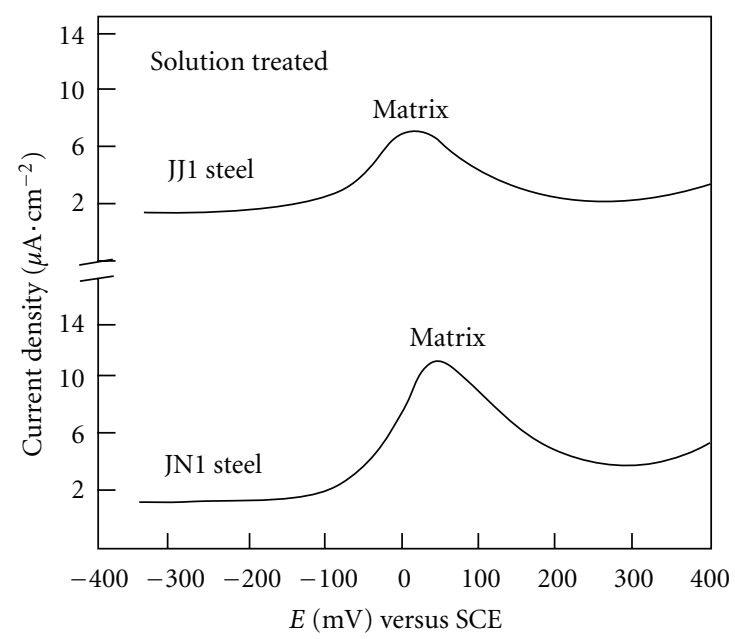

Figure 3: Anodic polarization curves of JJ1 steel and JN1 steel solution treated.

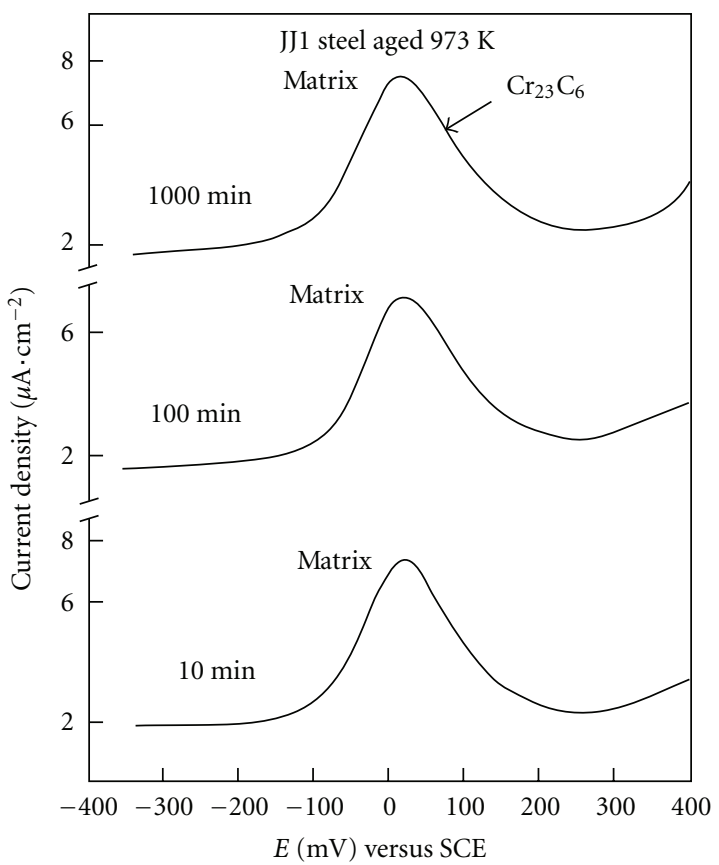

FIgure 4: Anodic polarization curves of JJ1 steel aged at $973 \mathrm{~K}$ for 10,100 , and $1000 \mathrm{~min}$.

shown in Figure 3. There is only one dissolution peak located at a potential of about 25 and $50 \mathrm{mV}$ in the anodic polarization curve of JJ1 and JN1 steel, respectively. This anodic peak can be associated with the dissolution of the austenitic matrix. It can also be noticed that the current density peak in the JN1 steel is higher than that in the JJ1 steel. This fact suggests that the dissolution of passive film is more difficult in the former because of its higher Cr content [9].

Figures 4 and 5 show the anodic polarization curves corresponding to the JJ1 steel aged at $973 \mathrm{~K}$ for 10,100 and $1000 \mathrm{~min}$ and at $900^{\circ} \mathrm{C}$ for $10,100,500$, and $1000 \mathrm{~min}$, respectively. In the anodic curve of sample aged at $973 \mathrm{~K}$, it seems that there is only one dissolution peak, corresponding 


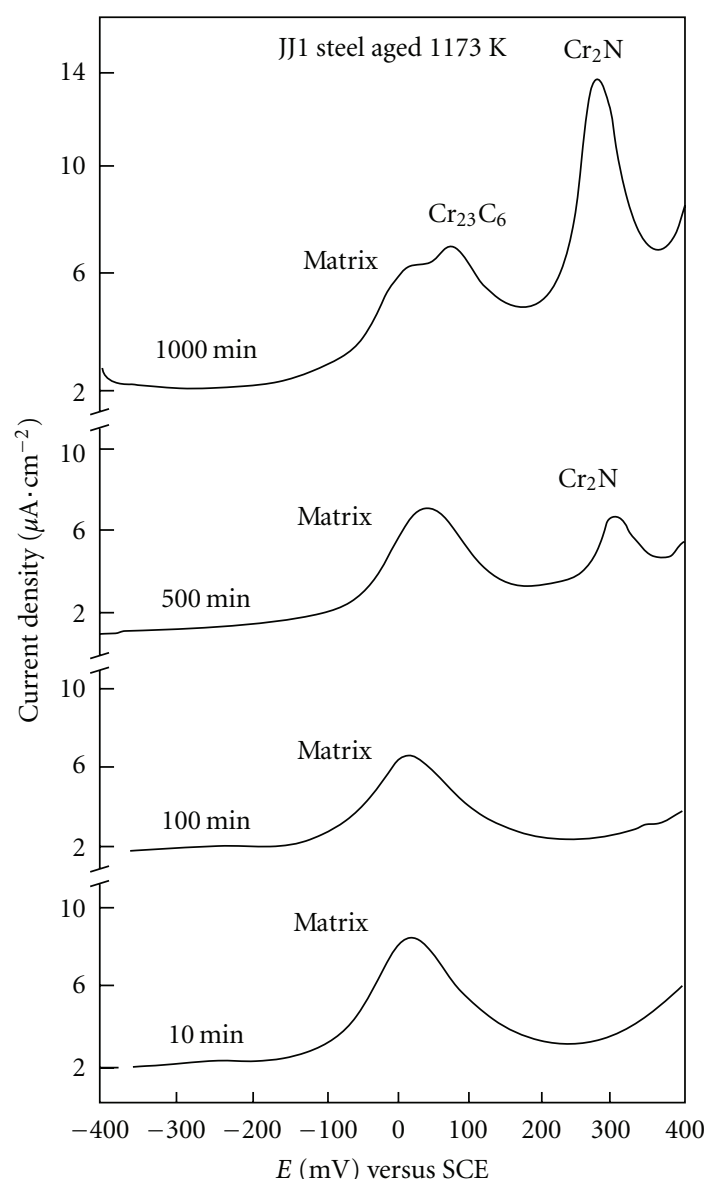

Figure 5: Anodic polarization curves of JJ1 steel aged at $1173 \mathrm{~K}$ for $10,100,500$, and $1000 \mathrm{~min}$.

to the austenitic matrix; however, a dissolution peak corresponding to the $\mathrm{Cr}_{23} \mathrm{C}_{6}$ carbide could be overlapped with that of the austenitic matrix, see anodic curve corresponding to the aging time of $1000 \mathrm{~min}$ in Figure 4 . This fact is more evident in the case the anodic curve of sample aged at $1173 \mathrm{~K}$ for $1000 \mathrm{~min}$, Figure 5, where the presence of three dissolution peaks can be observed. These peaks correspond to the austenitic matrix at about $25 \mathrm{mV}, \mathrm{Cr}_{23} \mathrm{C}_{6}$ carbide at about $75 \mathrm{mV}$, and $\mathrm{Cr}_{2} \mathrm{~N}$ nitride at about $250 \mathrm{mV}$. The $\mathrm{M}_{23} \mathrm{C}_{6}$ carbide dissolution peak has been reported to occur at 80 and $120 \mathrm{mV}$ in the aged SUS $316 \mathrm{H}$ and SUS 321 austenitic stainless steels, respectively [12]. Additionally, the $\mathrm{Cr}_{2} \mathrm{~N}$ nitride dissolution peak was observed to occur at about $250 \mathrm{mV}$ in a $\mathrm{Cr}_{2} \mathrm{~N}$ nitride specimen tested in the same solution in the present work. This fact shows a good agreement with the results of present work and it confirms that the austenitic matrix, $\mathrm{M}_{23} \mathrm{C}_{6}$ carbide, and $\mathrm{Cr}_{2} \mathrm{~N}$ nitride have characteristic dissolution peaks.

On the other hand, the anodic polarization curves for the JN1 steel samples aged at $973 \mathrm{~K}$ for 10,100 , and $1000 \mathrm{~min}$, and at $1173 \mathrm{~K}$ for $10,100,500$, and $1000 \mathrm{~min}$, are shown in Figures 6 and 7, respectively. Most of these anodic curves showed apparently only a dissolution peak, belonging to the austenitic matrix; however, thereis a clear and small discontinuity located at a potential of about $60 \mathrm{mV}$ in the matrix

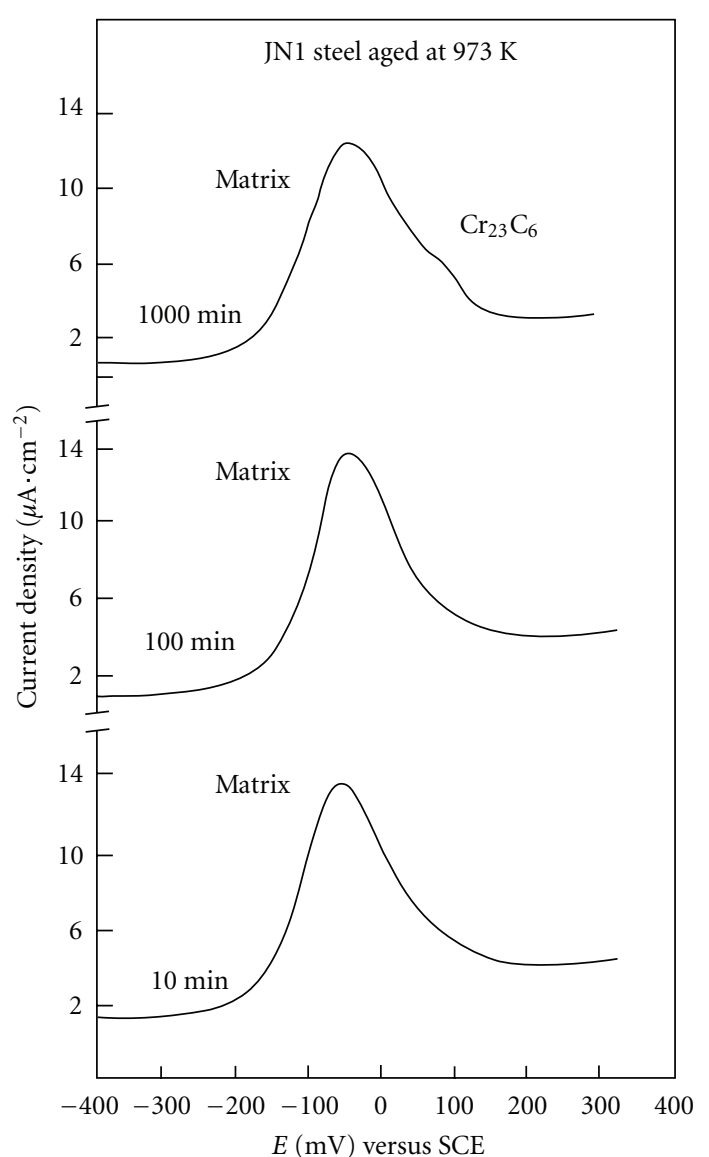

FIGURE 6: Anodic polarization curves of JN1 steel aged at $973 \mathrm{~K}$ for 10,100 , and $1000 \mathrm{~min}$.

dissolution peak for the sample aged at $973 \mathrm{~K}$ for $1000 \mathrm{~min}$. This fact suggests that the dissolution peak belongs to $\mathrm{Cr}_{23} \mathrm{C}_{6}$ carbide, and it is overlapped by the matrix. The anodic polarization curves of the JN1 steel sample aged at $1173 \mathrm{~K}$, Figure 7 , showed clearly the appearance of the $\mathrm{Cr}_{2} \mathrm{~N}$ nitride peak located at about $250 \mathrm{mV}$ as the aging time increased. In this case, there is small discontinuity in the matrix dissolution peak which also suggests that the $\mathrm{Cr}_{23} \mathrm{C}_{6}$ carbide dissolution peak is overlapped by that of the matrix. It is also important to mention that only one dissolution peak, corresponding to the austenite matrix, was detected for the JN1 and JJ1 steels aged at $873 \mathrm{~K}$ for times up to 500 and $200 \mathrm{~min}$, respectively.

To verify if each dissolution peak in the anodic curve can be attributed to the dissolution of either matrix or $\mathrm{Cr}_{23} \mathrm{C}_{6}$ and $\mathrm{Cr}_{2} \mathrm{~N}$ precipitates, the anodic swept of aged JJ1 and JN1 steel samples was stopped and maintained for $60 \mathrm{~min}$ at the potential of the different dissolution peaks and then these specimens were observed with a SEM. After this, the anodic swept was restarted from the last potential. For example, Figures 8(a) and 8(b) show the SEM micrographs of the JJ1 steel aged at $1173 \mathrm{~K}$ for $1000 \mathrm{~min}$ and then electrolytically tested and stopped at 25 and $75 \mathrm{mV}$, respectively. The SEM micrograph corresponding to dissolution potential of matrix, $25 \mathrm{mV}$ only revealed the microstructure, and thus both 


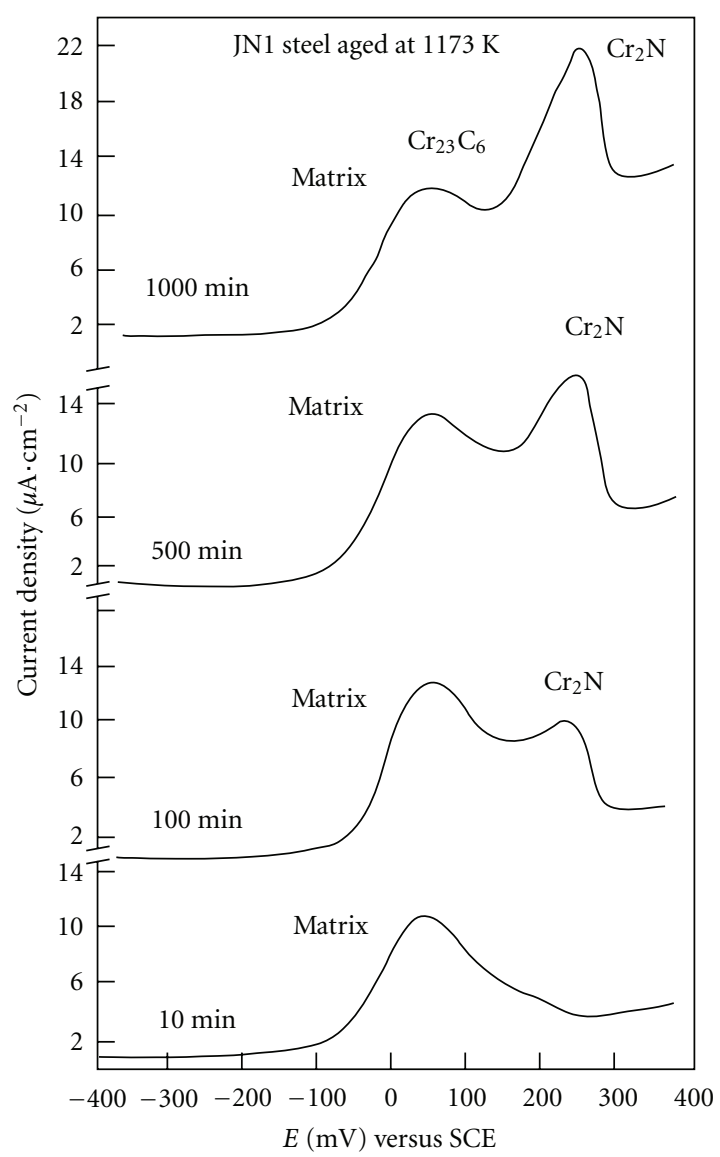

FIGURE 7: Anodic polarization curves of JN1 steel aged at $1173 \mathrm{~K}$ for $10,100,500$, and $1000 \mathrm{~min}$.

transgranular and intergranular precipitates are observed in Figure 8(a). In contrast, Figure 8(b) presents the SEM micrograph of specimen stopped at $75 \mathrm{mV}$. It can be noticed the preferential dissolution of some intergranular precipitates which seems to confirm the selectivity dissolution of the anodic polarization method. This preferential dissolution can be attributed to the fact that grain boundaries are disordered misfit regions separating grains of different crystallographic orientation. Thus, they are favored sites for the segregation of various elements or the precipitation of different phase. It is not surprising, therefore, that grain boundaries can be preferentially attacked in certain solutions [9].

It is important to remark that the current density of dissolution peaks from $\mathrm{Cr}_{23} \mathrm{C}_{6}$ carbide and $\mathrm{Cr}_{2} \mathrm{~N}$ nitride increases with aging time, see for instance Figures 5 and 7. This can be attributed to the increase in the volume fraction of precipitation. In general, it was observed the presence of $\mathrm{Cr}_{23} \mathrm{C}_{6}$ carbide and $\mathrm{Cr}_{2} \mathrm{~N}$ nitride increased as the aging time and temperature increased. Besides, it is important to mention that almost no dissolution peaks corresponding to precipitation were detected for the JN1 and JJ1 steels aged at $873 \mathrm{~K}$. These electrochemical results agree with the results of microstructural characterization.

3.3. Cryogenic Toughness. Figures $9(\mathrm{a})$ and $9(\mathrm{~b})$ show the plots of $\mathrm{CVN}$ fracture energyat $77 \mathrm{~K}$ versus aging time for the

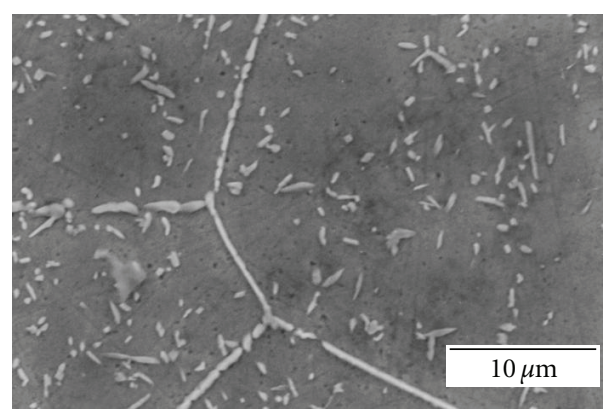

(a)

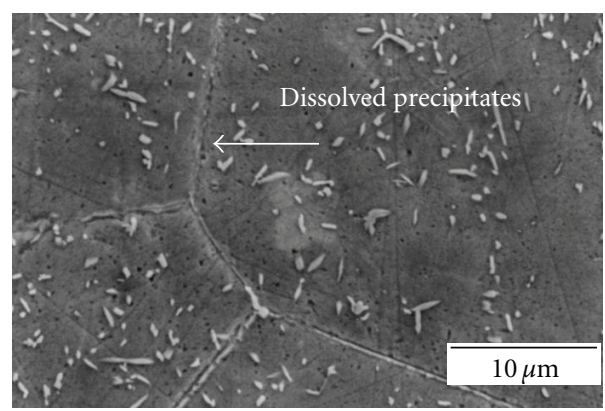

(b)

FIGURE 8: SEM micrographs of the electrolytically tested JJ1 steel after aging at $1123 \mathrm{~K}$ for $1000 \mathrm{~min}$ (a) at $25 \mathrm{mV}$ and (b) at $75 \mathrm{mV}$ in Figure 5 .

JJ1 and JN1 steels, respectively, aged at 973, 1073, and $1173 \mathrm{~K}$. All the steels showed a monotonic decrease in the CVN fracture energy with the aging time at the three temperatures. It is also evident that the drop of fracture toughness of JN1 steel is always faster than that of JJ1 steel. The fastest drop of fracture toughness occurred in the JN1 samples aged at $1173 \mathrm{~K}$. This fact may be attributed to the higher content of $\mathrm{C}$ and $\mathrm{N}$ in JN1 steel, which can lead to faster kinetics in intergranular precipitation during the aging process, as discussed in a later section.

The solution JN1, and JJ1 steels fractured in a ductile manner, see for example Figure 10(a), while the intergranular facets were found in all the aged samples, although the area fraction of intergranular facets to ductile surface was strongly dependent on the aging conditions. The fraction of intergranular brittle fracture increased with the aging time and temperature, see for instance Figures 10(b) and 10(c), and it seemed consistent with the CVN fracture energy value.

\section{Discussion}

4.1. Precipitation Kinetics. Figures 11 and 12 show the time temperature precipitation diagrams for JJ1 and JN1 steel samples, respectively, which summarize the phases detected in the aged samples by the anodic polarization curves for these steels. It is clear from these figures that the intergranular precipitation sequence is the following:

$$
\begin{array}{r}
\text { austenite } \longrightarrow \text { austenite }+\mathrm{Cr}_{23} \mathrm{C}_{6} \\
\longrightarrow \text { austenite }+\mathrm{Cr}_{23} \mathrm{C}_{6}+\mathrm{Cr}_{2} \mathrm{~N} .
\end{array}
$$




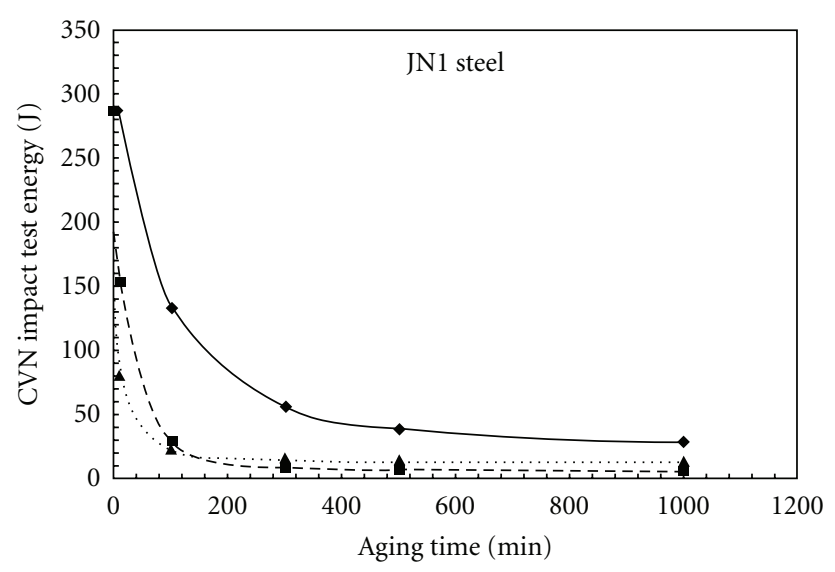

(a)

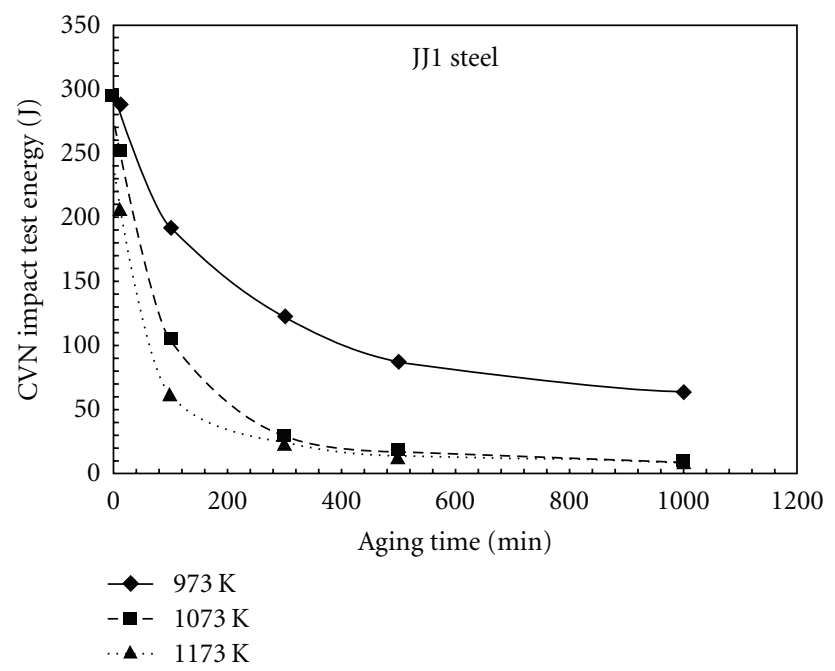

(b)

Figure 9: CVN fracture energy at $77 \mathrm{~K}$ as a function of aging time for (a) JN1 and (b) JJ1 steels aged at 973, 1073, and $1173 \mathrm{~K}$.

It can also be observed that of intergranular precipitation for the JN1 steel is faster than that of the JJ1 steel because of its higher-interstitial solute content. In general, these precipitation characteristics show a good agreement with the XRD and SEM microstructural characterization of these two steels. It is important to mention that the electrochemical test could not detect the presence of the transgranular $\eta$ phase precipitates since this test dissolves preferentially the intergranular precipitates, as explained above. Additionally, same type of TTP diagrams has been reported for these steels using metallographic techniques [13].

4.2. Effect of Precipitation on Toughness. The highest degradation in toughness for JN1 steel is associated with the volume fraction of intergranular precipitation formed during the thermal aging, as shown by the electrochemical analysis. An abundant presence of intergranular precipitates causes the reduction of cohesive strength of grain boundaries [14]. This is also confirmed by the increase in the intergranular brittle fracture as the thermal aging progresses. According to

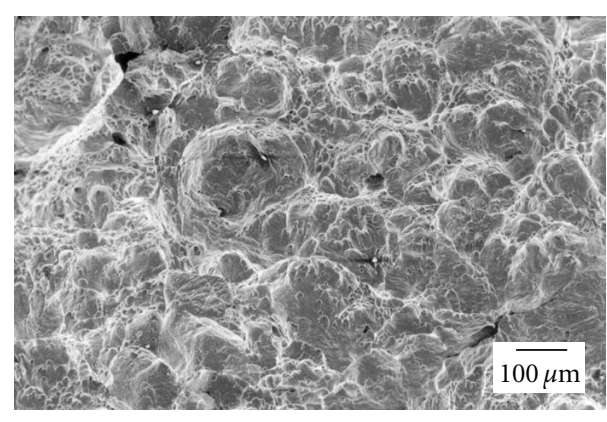

(a)

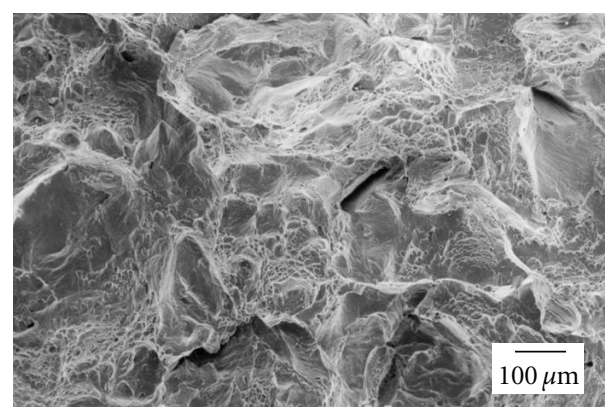

(b)

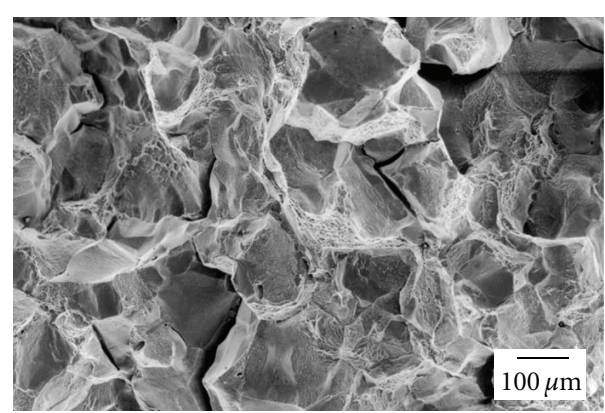

(c)

FIGURE 10: SEM fractographs of CVN impact test specimens for the JN1 steel (a) solution treated and aged at $1173 \mathrm{~K}$ for (b) 10 and (c) $1000 \mathrm{~min}$.

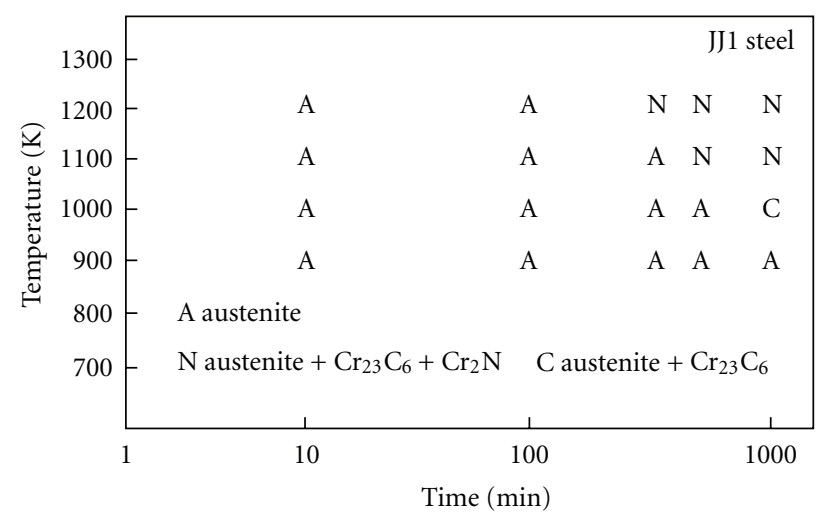

FIgURE 11: Time-temperature precipitation diagram of JJ1 steel. 


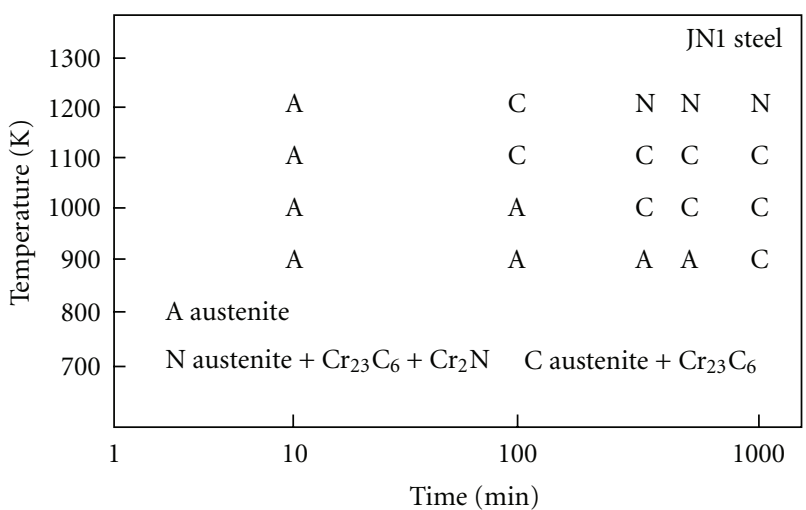

FIGURE 12: Time-temperature precipitation diagram of JN1 steel.

the results of electrochemical characterization, the presence of more than one peak in the anodic polarization curve seems to be enough to cause the aging-induced embrittlement. This embrittlement becomes more severe if the current density of dissolution peaks increases since the volume fraction of intergranular precipitates also increases. That is, the aginginduced embrittlement might be evaluated by means of this electrochemical method.

\section{Conclusions}

The electrochemical analysis of the aged JJ and JN steels conducted to the following conclusions.

(1) The anodic polarization test in a $1 \mathrm{~N} \mathrm{KOH}$ solution permitted to detect the presence of intergranular $\mathrm{Cr}_{23} \mathrm{C}_{6}$ carbide and $\mathrm{Cr}_{2} \mathrm{~N}$ nitride precipitates in the austenitic matrix.

(2) The volume fraction of intergranular precipitation is higher as the aging temperature and time increase for both the tested JN1 and JJ1 steels.

(3) The aging-induced embrittlement may be present if the dissolution peak of intergranular $\mathrm{Cr}_{23} \mathrm{C}_{6}$ carbide and $\mathrm{Cr}_{2} \mathrm{~N}$ nitride precipitates is detected in the anodic curve of the aged steels.

\section{Acknowledgment}

The authors wish to acknowledge the financial support from IPN-CONACYT 100584.

\section{References}

[1] P. Marshal, Austenitic Stainless Steels Microstructure and Properties, Elsevier, London, UK, 1st edition, 1990.

[2] V. G. Gavriljuk, "Nitrogen in iron and steel," ISIJ International, vol. 36, no. 7, pp. 738-745, 1996.

[3] H. Nakajima, K. Yoshida, and S. Shimamoto, "Development of new cryogenic steels for the superconducting magnets of the Fusion Experimental Reactor," ISIJ International, vol. 30, no. 8, pp. 567-578, 1990.
[4] K. Suemune, T. Sakamoto, T. Ogawa et al., "Manufacture and properties of nitrogen-containing $\mathrm{Cr}-\mathrm{Mn}$ and $\mathrm{Cr}-\mathrm{Ni}$ austenitic stainless steels for cryogenic use," Advances in Cryogenic Engineering, vol. 34, pp. 123-129, 1998.

[5] H. Nakajima, H. Nunoya, M. Nozawa et al., "Development of high strength austenitic stainless steel for conduit of $\mathrm{Nb}_{3}$ $\mathrm{Al}$ conductor," Advances in Cryogenic Engineering, vol. 42, pp. 323-330, 1996.

[6] L. P. Stoter, "Thermal ageing effects in AISI type 316 stainless steel," Journal of Materials Science, vol. 16, no. 4, pp. 10391051, 1981.

[7] J. W. Simmons, B. S. Covino, J. A. Hawk, and J. S. Dunning, "Effect of nitride $\left(\mathrm{Cr}_{2} \mathrm{~N}\right)$ precipitation on the mechanical, corrosion, and wear properties of austenitic stainless steel," ISIJ International, vol. 36, no. 7, pp. 846-854, 1996.

[8] J. W. Simmons, D. G. Atteridge, and J. C. Rawers, "Sensitization of high-nitrogen austenitic stainless steels by dichromium nitride precipitation," Corrosion, vol. 50, no. 7, pp. 491-501, 1994.

[9] A. J. Sedrinks, Corrosion of Stainless Steels, New Interscience Publication, New York, NY, USA, 1st edition, 1995.

[10] M. L. Saucedo-Muñoz, V. M. Lopez-Hirata, E. O. Avila-Davila, and D. V. Melo-Maximo, "Evaluation of toughness deterioration by an electrochemical method in an isothermally-aged $\mathrm{N}$-containing austenitic stainless steel," Materials Characterization, vol. 60, no. 2, pp. 119-124, 2009.

[11] D. A. Porter and K. E. Easterling, Phase Transformation in Metals and Alloys, Chapman \& Hall, London, UK, 2nd edition, 2005.

[12] Y. Saito, T. Shoji, and Y. Watanabe, "Development of nondestructive on-site measurement techniques by means, of an electrochemical method for material degradation of S/H SUS steel tubes of fossil boilers," Transactions of the Japan Society of Mechanical Engineers, vol. 57, no. 538, pp. 1442-1448, 1991.

[13] M. L. Saucedo-Muñoz, T. Hashida, Y. Watanabe, T. Shoji, and V. M. Lopez-Hirata, "Effect of precipitation on cryogenic toughness in N-containing austenitic stainless steels," Materials Science Forum, vol. 539-543, no. 5, pp. 4914-4919, 2007.

[14] W. J. Muster and J. Elster, "Low temperature embrittlement after ageing stainless steels," Cryogenics, vol. 30, no. 9, pp. 799$802,1990$. 

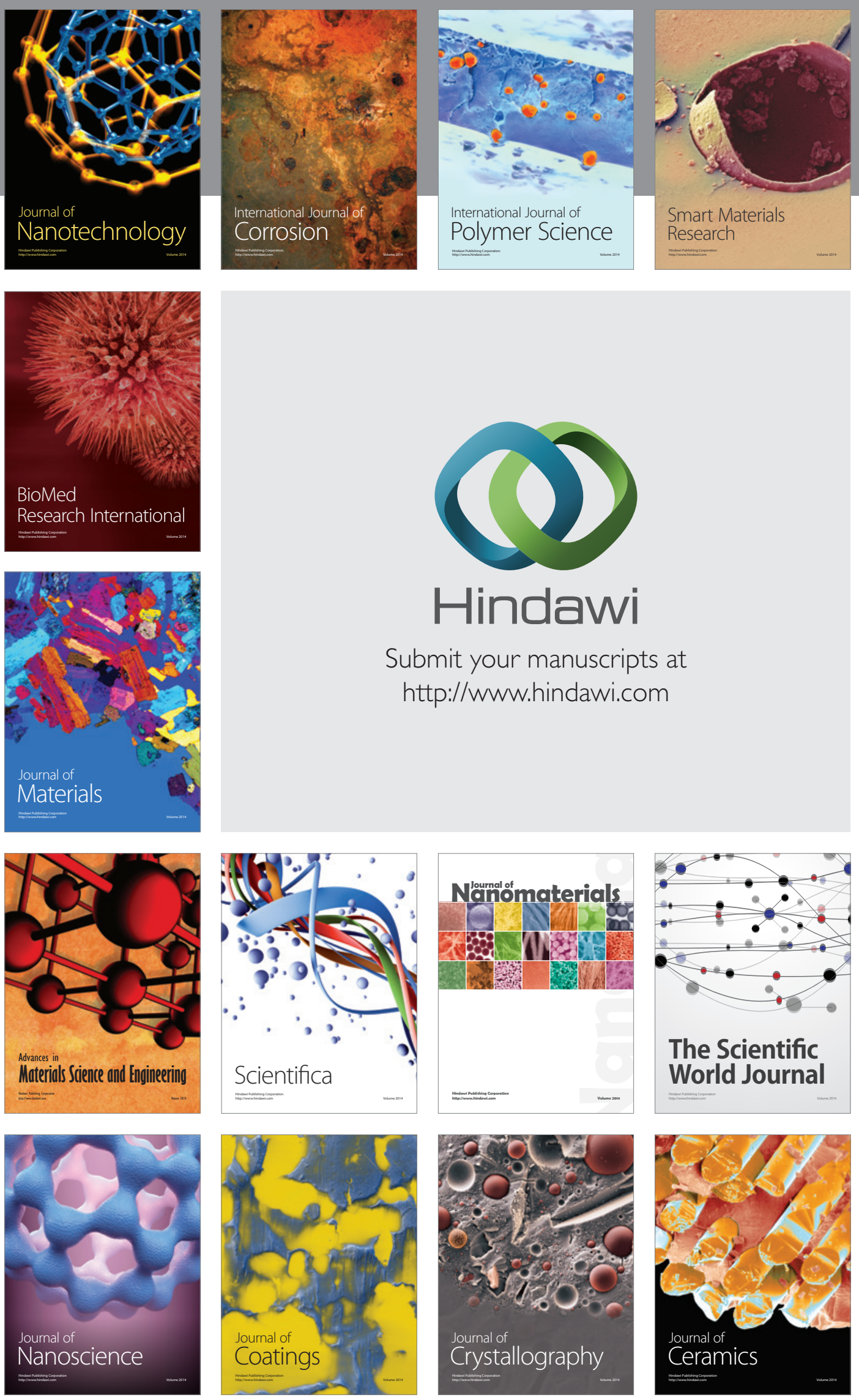

The Scientific World Journal

Submit your manuscripts at

http://www.hindawi.com

\section{World Journal}

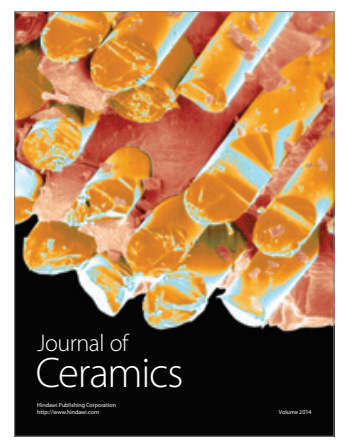

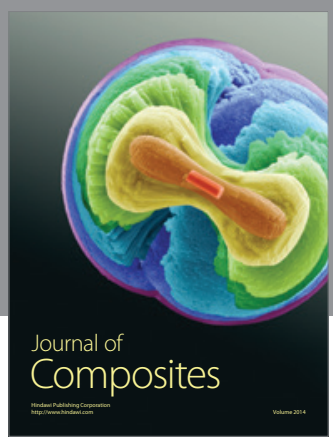
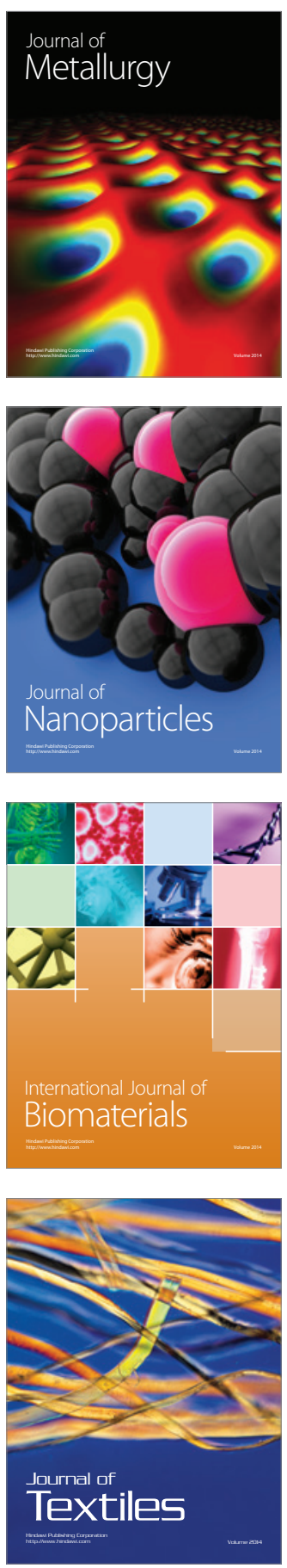